\title{
1. Graduate migration and regional development: an international perspective
}

\section{Jonathan Corcoran and Alessandra Faggian}

\subsection{BACKGROUND: GRADUATE MIGRATION AND REGIONAL DEVELOPMENT}

The number of tertiary-educated immigrants in OECD countries over the decade prior to 2011 increased by 70 per cent to reach 27 million people (OECD, 2013). The number of students seeking education abroad continues to increase, but there is also increasing competition from regional destinations that offer more affordable education prospects which may be more culturally relevant (UNESCO Institute for Statistics, 2016). Student and graduate migration form an integral part of the cross-border mobility of the intellectual elite (Lowell et al., 2004). In 2013, over 4.1 million people were studying abroad, meaning that 2 in 100 students globally were enrolled at a tertiary institution outside of their home country (UNESCO Institute for Statistics, 2016). This suggests that despite the trajectory of immigration rates slowing in recent years, university students and recent graduates have a consistently high degree of spatial mobility (Carree and Kronenberg, 2014).

While the United States, United Kingdom, Australia and France remain the most sought after destinations for students seeking high-quality education, student-based immigration is spreading to new countries and to regional hubs trying to expand their intellectual capital by attracting international students (UNESCO Institute for Statistics, 2016). Attracting international students is critical because many of these highly educated individuals remain in their host countries at the conclusion of their studies, increasing the human capital of the country and providing economic and intellectual gains. Within each host country, regions that have higher rates of education, such as the larger cities, may gain additional benefits. Understanding the locational choices of graduates is essential both at an international and regional level to shape local economic development 
and help the regions bearing the consequences of a loss of knowledge, technology transfer, investments and trade.

As our economies shift towards a knowledge-based focus, human capital is becoming increasingly relevant (Dotti et al., 2013), and areas with low levels of human capital experience limited growth (Haapanen and Tervo, 2012). According to Rowe et al. (2013, p. 179), a 'recognition of the importance of overseas graduates has led many industrialised nations to develop new immigration policies, targeted specifically at this segment of the foreign population'. Thus many countries are strategically focused on attracting highly educated migrants.

\subsubsection{The Importance of Human Capital}

Human capital is essential for growth and development (Corcoran et al., 2010; Faggian and McCann, 2009). Indeed, a region's human capital is one of the strongest predictors of sustained economic vitality (Abel and Deitz, 2012), as it is linked to increases in economic and population growth, wages, income and innovation (Florida et al., 2008). Empirical evidence suggests that local development is fostered by the presence of a skilled labour pool, which generates knowledge spill-overs and human capital externalities in turn increasing productivity and high-technology activities (Consoli et al., 2013). Ahlin et al. (2014) find that the spatial distribution of human capital is vital in explaining the long-term dynamics of the geography of jobs, incomes and well-being. Highly educated and highly skilled people are a sought-after resource as they are an irreplaceable element for economic success. Shapiro (2006) reports that from 1940 to 1990, a 10 per cent increase in rates of university education led to a 0.8 per cent increase in employment growth in the United States. Thus, graduate migrants are an 'increasingly numerous and strategically important' fraction of the population (King and Ruiz-Gelices, 2003, p. 229). They embody newly acquired knowledge and skills, and they are usually more mobile in their choice of where to enter the labour market after graduation (Ahlin et al., 2014). For this reason, regions with a university nearby have a consistent flow of tertiary-educated human capital, providing economic advantages over other regions (Haapanen and Tervo, 2012). Irrespective of the contextual differences in the countries analysed, human capital emerges as a key ingredient for economic growth and development.

\subsubsection{Human Capital and Migration}

On completion of a college or university degree, a graduate will move to a new region or country if there is a greater requirement for their acquired 
skills in the new area (Winters, 2012). Evidence shows that in Britain, about 60 per cent of graduates migrate to a new region after graduation (Faggian et al., 2007), while studies in the United States show that 33 per cent of doctoral students migrate after graduation (Stephan et al., 2004). Graduates will base a decision to migrate on a number of factors such as wage and employment opportunities, the local cost of living, amenities and quality of life, as well as their household and family circumstances (Franklin, 2003; Winters, 2012). Young college graduates are often attracted to large metropolitan areas with high wages and a strong labour market, and cultural and recreational amenities may play a further part in college graduate migration decisions. Individual employment outcomes and benefits of education are therefore inherently tied to location decisions (Oosterbeek and Webbink, 2011).

When looking at migration benefits, it is important to remember that migrants are also self-selected (Détang-Dessendre et al., 2004; Kazakis and Faggian, 2016) and hence not representative of the general population. For instance, students with higher grades and qualifications from more prestigious universities, having more employment options upon graduation, tend to be more mobile (Baryla Jr and Dotterweich, 2001; Faggian et al., 2007). There are also clear differences in migration propensity due to other personal characteristics such as marital status, ethnicity, previous migration, and family connections (Faggian et al., 2006; 2007; Mulder and Clark, 2002). Life cycle also plays a role. The propensity to move, for instance, is at its highest within the first couple of years after graduation (Haapanen and Tervo, 2009). Rérat (2014) refers to a triple biography in understanding decisions to migrate. This includes the social familial trajectory (such as sex, household factors, socio-economic background, partners' characteristics); the migration trajectory (such as region of origin, parents' region of birth, location of university); and the professional trajectory (such as field of study, kind of degree, grants, job status, year of graduation). The individual may, in the course of their studies, develop networks inside or outside of their university that enhance their employment prospects in the area. Alternatively, recent graduates may have built strong friendships and grown accustomed to local amenities that make it difficult to move away after graduation. Indeed, these preferences for the place where they attended college may even incline some recent graduates to accept lower-paying jobs to stay in the area that they have grown to appreciate (Winters, 2012).

Along with the circumstances and preferences of the individual, there is also a need to consider regional characteristics that may influence an individual's decision. The probability of individual migration depends on employment rates and the availability of jobs, relative wage levels and cost 
of living, levels of income and employment growth rates, amenity variations and crime (Faggian et al., 2006; Venhorst et al., 2011). The availability of high-level jobs in the area is an important factor, as are the available amenities (Venhorst et al., 2011). The value of expected income is also key, as are potential career progressions and opportunities to increase skills (Di Cintio and Grassi, 2013). Conversely, adverse regional and national economic circumstances may stimulate spatial mobility, as migrants may need to search further afield for work (Venhorst et al., 2011). With this in mind, the less developed a country is, the more likely it is that the intellectual 'elites' of such a country choose to move away to further advance their education and career with a potential for brain drain (Szelényi, 2006).

\subsubsection{The Implications of Graduate Migration}

An emerging body of literature has investigated the potential positive and negative economic consequences of highly skilled migration both for individuals and for the sending and receiving countries (Rowe et al., 2013). A large and consistent loss of the intellectual elite of a region or country can have negative consequences for the economic, technological and trade assets in that area. This loss of the educated population, referred to in the literature as 'brain drain', depletes the human capital of the area (Lowell and Findlay, 2001; Szelényi, 2006). The implicit assumption that regions with local university educational options benefit from the gain in human capital is only true if these graduates remain in the region (Venhorst et al., 2010). Therefore, many regions place a high priority on retaining their graduates in attempts to maintain their human capital, and to encourage graduates to seek employment in the area to repay some of the cost of their education that was initially covered by the state or country (Krabel and Flöther, 2014). Brain drain is of particular concern for local governments in university towns that act as 'escalator regions' - that is, students enter the city to receive their education, and then move to another region to capitalise on the education they received (Abreu et al., 2014). Attracting and retaining graduates is vitally important to avoid this 'brain drain' and to maximise human capital in an area. In contrast to 'brain drain', 'brain gain' has been coined as a term for the educational and economic gains made by the countries that host highly skilled immigrants for extended periods, or in many cases, permanently (Szelényi, 2006). 


\subsection{STRUCTURE}

This book provides an international perspective on graduate migration. It centres around three key themes emerging from the literature: mobility and mismatch; push and pull migration factors; and migration and labourmarket outcomes. The book is structured into twelve chapters including this introduction. The remaining eleven chapters are organised according to the three themes mentioned above. Chapters 2 to 5 discuss mobility and mismatch, Chapters 6 to 8 focus on push-pull factors and Chapters 9 to 11 detail the labour market and wages for graduates.

\subsubsection{Mobility and Mismatch}

While new university graduates are geographically highly mobile, there is evidence that some of them - especially in certain fields such as the creative arts - struggle when entering the labour market, resorting to working in non-graduate-level jobs or in a field different from the one for which they are qualified (Abreu et al., 2015; Comunian et al., 2010). This also means that many graduates are not earning to their full remuneration potential. In the literature, mismatches are captured in three forms: qualification, field-of-study, and skill mismatches. Qualification mismatches occur when a graduate holds a higher qualification than is required for their job (Green and McIntosh, 2007). A field-of-study mismatch occurs when a graduate is employed in a field that does not align with their area of tertiary study (McGuinness and Byrne, 2015). A skills mismatch occurs when graduates do not employ the skills that they learnt during the course of their studies in their occupation, including key skills such as literacy, numeracy, problem solving and communication skills (McGowan and Andrews, 2015).

A number of studies on mismatch have concluded that a large share of graduates are over-educated for their jobs and earn less than their wellmatched peers. Although Rosen (1972) explains that this over-education may be a temporary consequence of graduates accepting lower-paid occupations which require fewer skills to increase their experience in the field to improve their chances of obtaining a more suitable job in the long-term (see also McGuinness and Byrne, 2015), this does not explain all of the mismatch that occurs. Furthermore, there is evidence of gender and age effects, as well as differences in mismatch across fields of study (Groot and Van Den Brink, 2000). In this book, studies from Australia, Canada, Italy and the Netherlands consider the mobility and mismatch of graduate populations between regions (Chapters 2 to 5).

Chapter 2, by Angelina Tang, Jonathan Corcoran and Francisco Rowe, examines the incidence of education-job mismatch amongst overseas 
students who remain in Australia after graduation. The authors conclude that post-graduation migration between local labour markets has marginal impacts on lowering the likelihood of experiencing field-of-study and skills mismatches, and that migration also increases the chances of having qualification mismatch as migrants tend to cluster in highly competitive labour markets within the largest capital cities. Chapter 3, by Bruce Newbold, considers the graduate migration behaviours of university graduates in Canada. This study identifies that individuals with higher levels of education, and more employment experience during their studies are more likely to migrate to labour-market opportunities following graduation, while individuals of a visible minority status were more likely to remain. Chapter 4, by Simona Iammarino and Elisabetta Marinelli, analyses the impact of inter-regional mobility on education-job match in the early stage of a graduate's professional career in Italy. Results from this study demonstrate that there are important regional differences in the probability of over-education and a mismatch of the graduate's skills and capabilities. Chapter 5, by Viktor Venhorst, details the effect of the household situation of the graduate's mobility after leaving a higher education institution in the Netherlands. It is concluded that the likelihood of labour-market dynamics varies strongly with the life-phase, with the likelihood of changes declining sharply within a few years of graduation.

\subsubsection{Push-Pull factors}

As we know from the wealth of scholarship on human migration, many key factors coalesce to influence an individual's decision to migrate. There are several economic and social forces within the home country that serve to 'push' graduates to another region or country with more opportunities. These factors may include poor employment prospects, limited economic opportunities, crime rates, or conflict. However, the decision as to which area they will select is dependent on a variety of 'pull' factors associated with that place. These include more opportunities for employment, higher wages, better facilities, more attractive working conditions, and suitable amenities. In this book, the push-pull factors of graduate migration are discussed in the context of Finland, France and Spain (Chapters 6 to 8).

Chapter 6, by Mika Haapanen and Hannu Karhunen, details the implications of working while studying in Finland. The authors note that migration rates are lower for students who have worked throughout their studies, particularly for those who worked full-time. Chapter 7, by Cécile Détang-Dessendre and Virginie Piguet, seeks to explain migration flows of young educated people in France. These findings demonstrate that graduate migration is predicted by the characteristics of local labour markets, 
rather than climates and amenities, particularly for individuals with higher levels of education. Chapter 8, by Raul Ramos and Vicente Royuela, analyses the effect of the Great Recession on emigration in Spain. Results show that graduates with higher grades are more prone to migrate, and that previous mobility experiences and foreign language knowledge also impact migration decisions.

\subsubsection{Graduate Migration and the Labour Market}

Wage discrepancies are noted in research on graduate migration. Specifically, substantial differences are noted in the wages of those who are repeat migrants (those who move to a university, and then move again to employment), return migrants (those who move away to study, and then return to the same region), and those who attend a university in their region of origin. There are also differences between salaries for males and females, with females reporting lower salaries in most conditions. In this book, studies on Mexico, the United States and the United Kingdom (Chapters 9 to 11) investigate the role of migration on salaries at different career points.

Chapter 9, by Norman Maldonado, describes the migration paths of graduates in Mexico. Results demonstrate that the more heterogeneous the migration path, the higher the wage premium. Chapter 10, by Alessandra Faggian, Jonathan Corcoran and Rachel Franklin, examines the salaries of graduates in the United States. Their evidence demonstrates that in the United States, unlike the United Kingdom, repeat migrants obtain the highest wage premium in terms of both mean and median wages. Chapter 11, by Roberta Comunian, Sarah Jewell and Alessandra Faggian, considers the effect of gender on graduate wages in the United Kingdom. Findings show that while late migration has the strongest effect on salaries for women, men earn higher salaries than women in most situations.

\section{REFERENCES}

Abel, J.R. and Deitz, R. (2012). Do colleges and universities increase their region's human capital? Journal of Economic Geography, 12(3), 667-691, doi: 10.1093/ jeg/lbr020.

Abreu, M., Koster, S. and Venhorst, V.A. (2014). Transitions and location choice: analysing the decisions of students and recent graduates. Spatial Economic Analysis, 9(4), 349-354, doi: 10.1080/17421772.2014.965552.

Abreu, M., Faggian, A. and McCann, P. (2015). Migration and inter-industry mobility of UK graduates. Journal of Economic Geography, 15(2), 353-385, doi: 10.1093/jeg/lbt043. 
Ahlin, L., Andersson, M. and Thulin, P. (2014). Market thickness and the early labour market career of university graduates: an urban advantage? Spatial Economic Analysis, 9(4), 396-419, doi: 10.1080/17421772.2014.961534.

Baryla Jr, E.A. and Dotterweich, D. (2001). Student migration: do significant factors vary by region? Education Economics, 9(3), 269-280.

Carree, M.A. and Kronenberg, K. (2014). Locational choices and the costs of distance: empirical evidence for Dutch graduates. Spatial Economic Analysis, 9(4), 420-435.

Cintio, M. di and Grassi, E. (2013). Internal migration and wages of Italian university graduates. Papers in Regional Science, 92(1), 119-140.

Comunian, R., Faggian, A. and Li, Q.C. (2010). Unrewarded careers in the creative class: the strange case of bohemian graduates. Papers in Regional Science, 89(2), 389-410.

Consoli, D., Vona, F. and Saarivirta, T. (2013). Analysis of the graduate labour market in Finland: spatial agglomeration and skill-job match. Regional Studies, 47(10), 1634-1652.

Corcoran, J., Faggian, A. and McCann, P. (2010). Human capital in remote and rural Australia: the role of graduate migration. Growth and Change, 41(2), 192-220, doi: 10.1111/j.1468-2257.2010.00525.x.

Détang-Dessendre, C., Drapier, C. and Jayet, H. (2004). The impact of migration on wages: empirical evidence from French youth. Journal of Regional Science, 44(4), 661-691.

Dotti, N.F., Fratesi, U., Lenzi, C. and Percoco, M. (2013). Local labour markets and the interregional mobility of Italian university students. Spatial Economic Analysis, 8(4), 443-468.

Faggian, A. and McCann, P. (2009). Human capital and regional development. In R. Capello and P. Nijkamp (eds), Handbook of Regional Growth and Development Theories, Cheltenham, UK and Northampton, MA: Edward Elgar, pp. 133-151.

Faggian, A., McCann, P. and Sheppard, S. (2006). An analysis of ethnic differences in UK graduate migration behaviour. The Annals of Regional Science, 40(2), 461-471.

Faggian, A., McCann, P. and Sheppard, S. (2007). Some evidence that women are more mobile than men: gender differences in UK graduate migration behavior. Journal of Regional Science, 47(3), 517-539.

Florida, R., Mellander, C. and Stolarick, K. (2008). Inside the black box of regional development: human capital, the creative class and tolerance. Journal of Economic Geography, 8(5), 615-649, doi: 10.1093/jeg/lbn023.

Franklin, R.S. (2003). Migration of the young, single, and college educated, 1995-2000. Special report, US Department of Commerce, Economics and Statistics Administration, US Census Bureau, available at: https://usa.ipums. org/usa/resources/voliii/pubdocs/2000/censr-12.pdf.

Green, F. and McIntosh, S. (2007). Is there a genuine under-utilization of skills amongst the over-qualified? Applied Economics, 39(4), 427-439.

Groot, W. and Van Den Brink, H.M. (2000). Overeducation in the labor market: a meta-analysis. Economics of Education Review, 19(2), 149-158.

Haapanen, M. and Tervo, H. (2009). Return and onward migration of highly educated: evidence from residence spells of Finnish graduates. Working paper, School of Business and Economics, University of Jyväskylä.

Haapanen, M. and Tervo, H. (2012). Migration of the highly educated: evidence 
from residence spells of university graduates. Journal of Regional Science, 52(4), 587-605.

Kazakis, P. and Faggian, A. (2016). Mobility, education and labor market outcomes for U.S. graduates: is selectivity important? Annals in Regional Science, doi: 10.1007/s00168-016-0773-6.

King, R. and Ruiz-Gelices, E. (2003). International student migration and the European 'year abroad': effects on European identity and subsequent migration behaviour. International Journal of Population Geography, 9(3), 229-252, doi: 10.1002/ijpg.280.

Krabel, S. and Flöther, C. (2014). Here today, gone tomorrow? Regional labour mobility of German university graduates. Regional Studies, 48(10), 1609-1627.

Lowell, B.L. and Findlay, A. (2001). Migration of highly skilled persons from developing countries: impact and policy responses. Synthesis report, International Migration Papers, p. 44.

Lowell, B.L., Findlay, A. and Stewart, E. (2004). Brain strain: optimising highly skilled migration from developing countries. Institute for Public Policy Research Working Paper, 3.

McGowan, M.A. and Andrews, D. (2015). Labour market mismatch and labour productivity. OECD Economics Department Working Papers, doi: 10.1787/18151973.

McGuinness, S. and Byrne, D. (2015). Born abroad and educated here: examining the impacts of education and skill mismatch among immigrant graduates in Europe. IZA Journal of Migration, 4(1), 1-30, doi: 10.1186/s40176-015-0039-6.

Mulder, C.H. and Clark, W.A. (2002). Leaving home for college and gaining independence. Environment and Planning A, 34(6), 981-999.

OECD (2013). World migration in figures, available at: https://www.oecd.org/els/ mig/World-Migration-in-Figures.pdf.

Oosterbeek, H. and Webbink, D. (2011). Does studying abroad induce a brain drain? Economica, 78(310), 347-366.

Rérat, P. (2014). The selective migration of young graduates: which of them return to their rural home region and which do not? Journal of Rural Studies, 35, $123-132$.

Rosen, S. (1972). Learning and experience in the labor market. Journal of Human Resources, 7(3), 326-342.

Rowe, F., Corcoran, J. and Faggian, A. (2013). Mobility patterns of overseas human capital in Australia: the role of a 'new' graduate visa scheme and rural development policy. Australian Geographer, 44(2), 177-195.

Shapiro, J.M. (2006). Smart cities: quality of life, productivity, and the growth effects of human capital. The Review of Economics and Statistics, 88(2), 324-335.

Stephan, P.E., Sumell, A.J., Black, G.C. and Adams, J.D. (2004). Doctoral education and economic development: the flow of new PhDs to industry. Economic Development Quarterly, 18(2), 151-167.

Szelényi, K. (2006). Students without borders? Migratory decision-making among international graduate students in the US. Knowledge, Technology and Policy, 19(3), 64-86.

UNESCO Institute for Statistics (2016). Global flow of tertiary educated students, available at: http://www.uis.unesco.org/Education/Pages/international-studentflow-viz.aspx.

Venhorst, V., Van Dijk, J. and Van Wissen, L. (2010). Do the best graduates leave the peripheral areas of the Netherlands? Tijdschrift voor economische en sociale geografie, 101(5), 521-537. 
Venhorst, V., Van Dijk, J. and Van Wissen, L. (2011). An analysis of trends in spatial mobility of Dutch graduates. Spatial Economic Analysis, 6(1), 57-82.

Winters, J.V. (2012). Differences in employment outcomes for college town stayers and leavers. IZA Journal of Migration, 1(1), 1-17. 